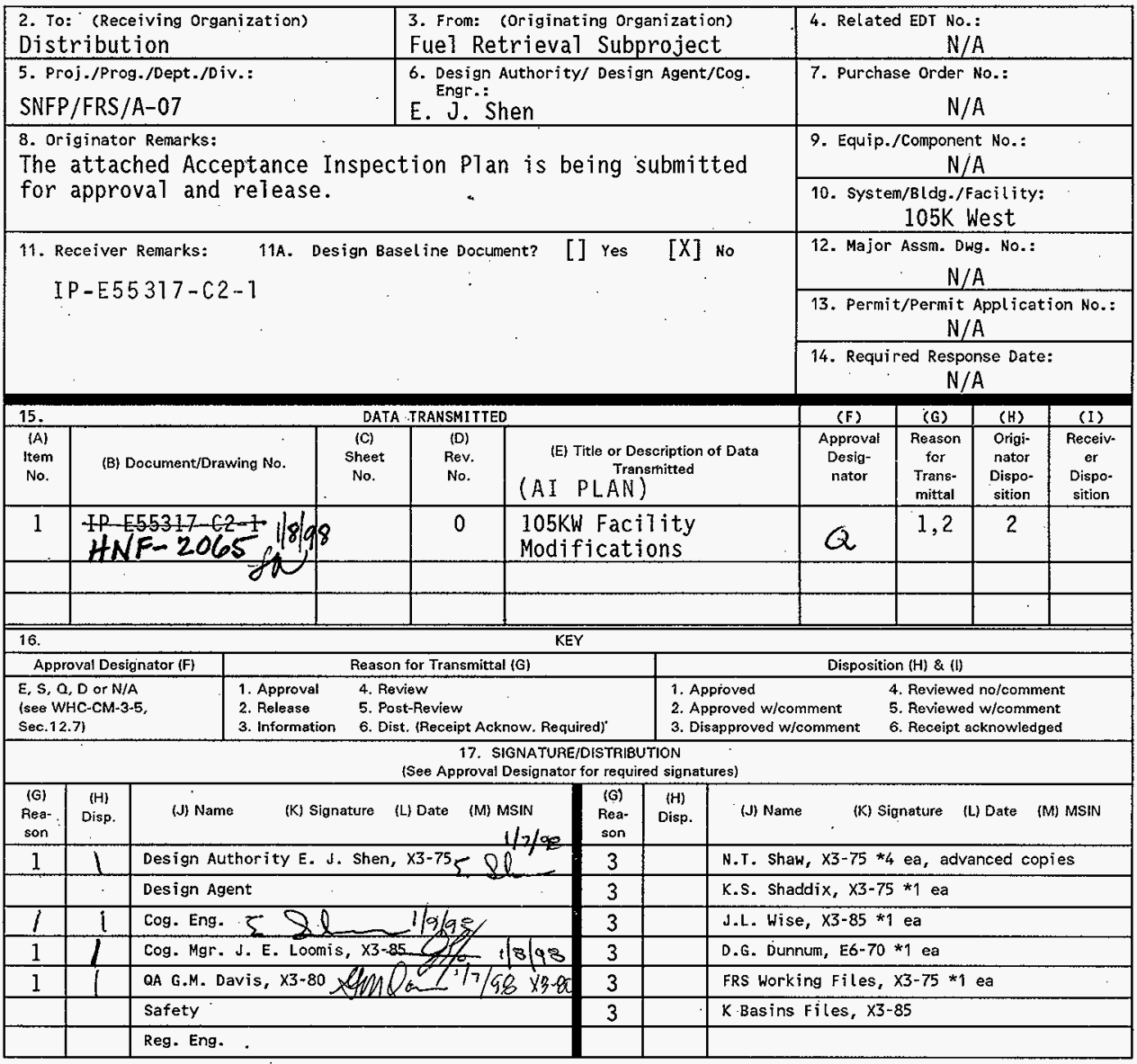

\begin{tabular}{|c|c|c|c|}
\hline E.J. Shen $\$$ Lock 17 & 19. & $\begin{array}{l}20 . \\
\text { J.E. Loomis, } \\
\text { QCLCLK } 1 \% 7\end{array}$ & $\begin{array}{l}\text { 21. DOE APPROVAL (if requi red) } \\
\text { Ctrl. No. } \\
\text { [] Approved } \\
\text { [] Approved w/coments }\end{array}$ \\
\hline $\begin{array}{l}\text { Signature of EDT Date } \\
\text { Originator }\end{array}$ & $\begin{array}{l}\text { Authorized Representative Date } \\
\text { for Receiving Organization }\end{array}$ & $\begin{array}{l}\text { Design Authority } \\
\text { Cognizant Manager }\end{array}$ & [] D isapproved w/comments \\
\hline
\end{tabular}

BD-7400-172-2 (05/96) GEF097 
HNF-2065, Rev. 0

\section{ACCEPTANCE INSPECTION PLAN 105KW FACILITY MODIFICATIONS FOR FUEL RETRIEVAL SUBPROJECT}

E. J. Shen

Duke Engineering \& Services Hanford, Inc., Richland, WA 99352

U.S. Department of Energy Contract DE-AC06-96RL13200
EDT/ECN: 621122
Org Code: $2 \mathrm{~T} 371$
UC: N/A
B\&R Code: N/A
Charge Code: LDG02
Total Pages: /I

Key Words: Acceptance Inspection Plan; Fuel Retrieval Subproject, QA, $K$ West

Abstract:

TRADEMARK DISCLAIMER. Reference herein to any specific commercial product, process, or service by trade name, trademark, manufacturer, or otherwise, does not necessarily constitute or imply its endorsement, recomendation, or favoring by the United States Government or any agency thereof or its contractors or subcontractors.

Printed in the United States of America. To obtain copies of this document, contact: Document Control Services, P.O. Box 950, Mailstop H6-08, Richland WA 99352, Phone (509) 372-2420;

Fax (509) 376-4989.
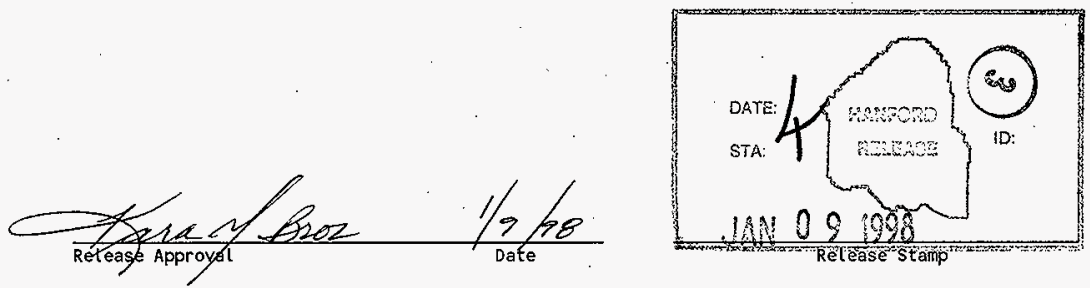

\section{Approved for Public Release}




\section{ACCEPTANCE INSPECTION PLAN \\ 105KW FACILITY MODIFICATIONS \\ FOR \\ FUEL RETRIEVAL SUBPROJECT}

HNF-2065, Rev. 0

AI PLAN NO. IP-E55317-C2-1

REVISION 0

\section{APPROVALS}
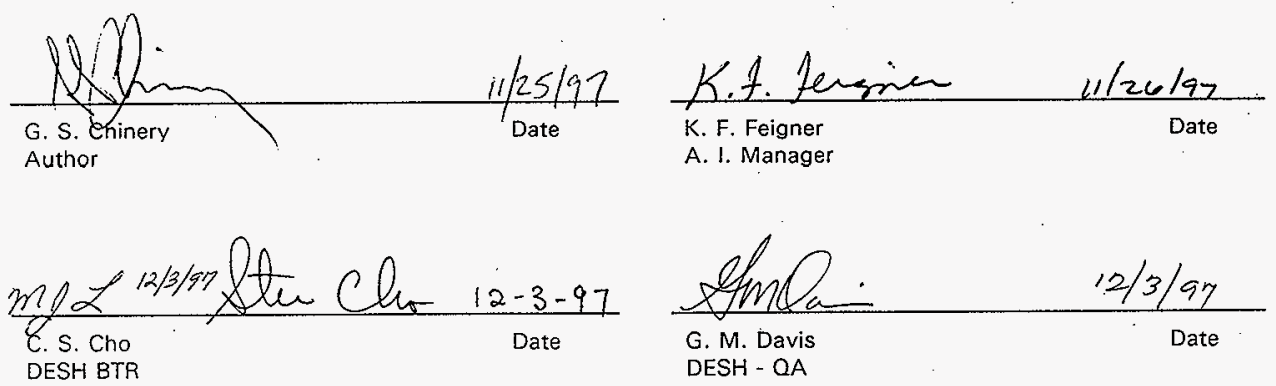

B. S. Carlisle

$(2-3-9)$

DESH BTR

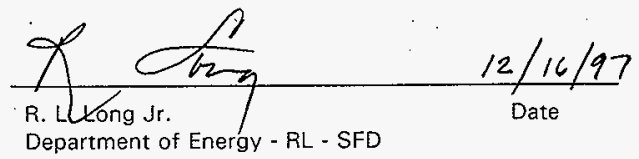




\section{TABLE OF CONTENTS}

Page

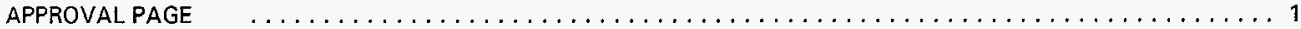

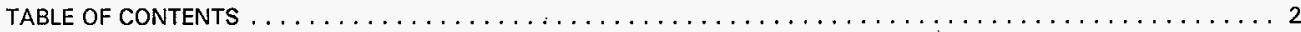

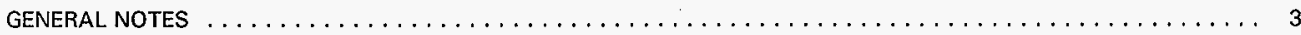

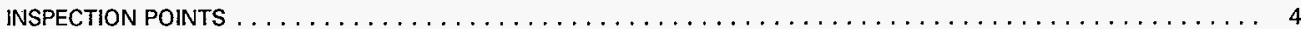

GENERAL VERIFICATIONS AND SURVEILLANCES $\ldots \ldots \ldots \ldots \ldots \ldots \ldots \ldots \ldots \ldots \ldots$

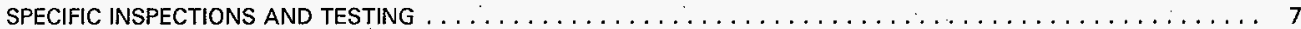

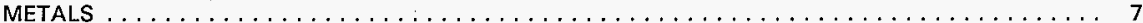

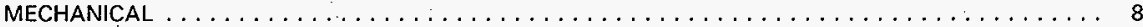

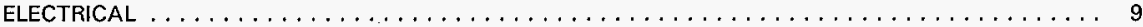

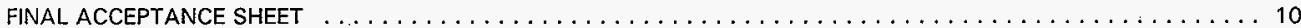




\section{GENERAL NOTES}

The acceptance inspection of construction by Fluor Daniel Hanford (FDH) is performed to provide assurance that fabrication, construction, and installation are in accordance with approved contract documents. Approved contract documents used to perform inspections may include specifications, drawings, and contractor submittals such as fabrication drawings, procedures, etc. The amount or degree of inspection activity is tailored to the project as determined by the project team so that the effort and cost expended are commensurate with the importance of the facility in terms of function and safety. Inspections are documented to provide verification of the acceptability of the work performed.

This document identifies the inspections and documentation forms to be provided. It is prepared and implemented with the understanding that the construction contractor is fully responsible for compliance with contract documents and for the quality of work performed. Inspections performed are in accordance with approved procedures.

The Manager of Acceptance Inspection is responsible for the implementation of this plan and assignment of personnel for the work. Inspections are conducted by personnel who are qualified and certified to perform their assigned task.

The Acceptance Inspection Plan is organized in the Construction Specification Institute (CSI) format to cross reference design specification sections with sections of the Al Plan. In each Al Plan section the applicable specification section subject will be identified followed by the appropriate inspection requirements. General surveillances will be listed when applicable.

Acceptance Inspection Reports are provided to document inspections not documented on a test report (i.e. Soil Test Data, Concrete Test Report, NDE/Weld Record, Leak/Pressure Test Certification, Backflow Device Test Report, Nonconformance Report, Deficiency Report, and/or Contractors testing forms.) 


\section{INSPECTION POINTS}

The FDH Acceptance Inspection initial contact for performance of Inspection Points listed below is Dave Frey at $372-$ 2736. Names of assigned inspectors are provided during the initial contact.

RECEIVING INSPECTION POINTS (R) - Fabrications, equipment, and/or materials which have been selected for inspection by FDH upon arrival at a designated location, normaliy the jobsite. The contractor shall notify FDH Acceptance Inspection of the arrival of such items within four hours after receipt.

WITNESS POINTS (W) - Those activities in the sequence of construction which have been selected for inspection at the option of FDH Acceptance Inspection. The contractor shall notify FDH Acceptance Inspection at least twenty four hours (On-Site), or five days (Off-Site), in advance of scheduled activity. Work may proceed, however, upon verbal release by the FDH Acceptance Inspector, or upon the expiration of one hour past the scheduled time of activity.

HOLD POINTS $(H)$ - Those activities in the sequence of construction which have been selected for mandatory inspection by FDH Acceptance Inspection. The contractor shall notify FDH Acceptance Inspection at least twenty four hours (On-Site), or five days (Off-Site), in advance of scheduled activity. Work shall not proceed until the Acceptance Inspector completes all necessary inspections.

\begin{tabular}{|c|c|c|c|c|}
\hline $\begin{array}{l}\text { INSPECTION } \\
\text { POINT NO }\end{array}$ & INSPECTION POINT DESCRIPTION & $\begin{array}{c}\text { INSPECT } \\
\text { POINT }\end{array}$ & $\begin{array}{l}\text { OFF } \\
\text { SITE }\end{array}$ & $\begin{array}{l}\text { ON } \\
\text { SITE }\end{array}$ \\
\hline$\underline{05055}$ & EXPANSION ANCHOR INSTALLATIONS & & & \\
\hline $05055-1$ & INSTALLATION OF EXPANSION ANCHORS & W & & $x$ \\
\hline
\end{tabular}

05120

05120-1

05120-2

05120-3

15493-1

15493-2

15500

15500-1

16400

16400-1

16400-2

\section{STRUCTURAL STEEL}

INITIAL WELDING

LOAD TESTING OF MONORAILS

INSTALLATION OF SUPPORT STRUCTURE FOR THE FUEL MANIPULATOR

CHEMICAL PROCESS PIPING SYSTEMS

INITIAL WELDING

LEAK/PRESSURE TESTING

HEATING, VENTILATION, AND AIR CONDITIONING

LEAK/PRESSURE TESTING

SERVICE AND DISTRIBUTION

ACCEPTANCE TESTING

PRIOR TO ENERGIZING EQUIPMENT (NEC INSPECTION) w

$x$

W

W

w

$x$

W

w

$X$

$x$

$\begin{array}{ll}W & X \\ H & X\end{array}$


GENERAL VERIFICATIONS AND SURVEILLANCES

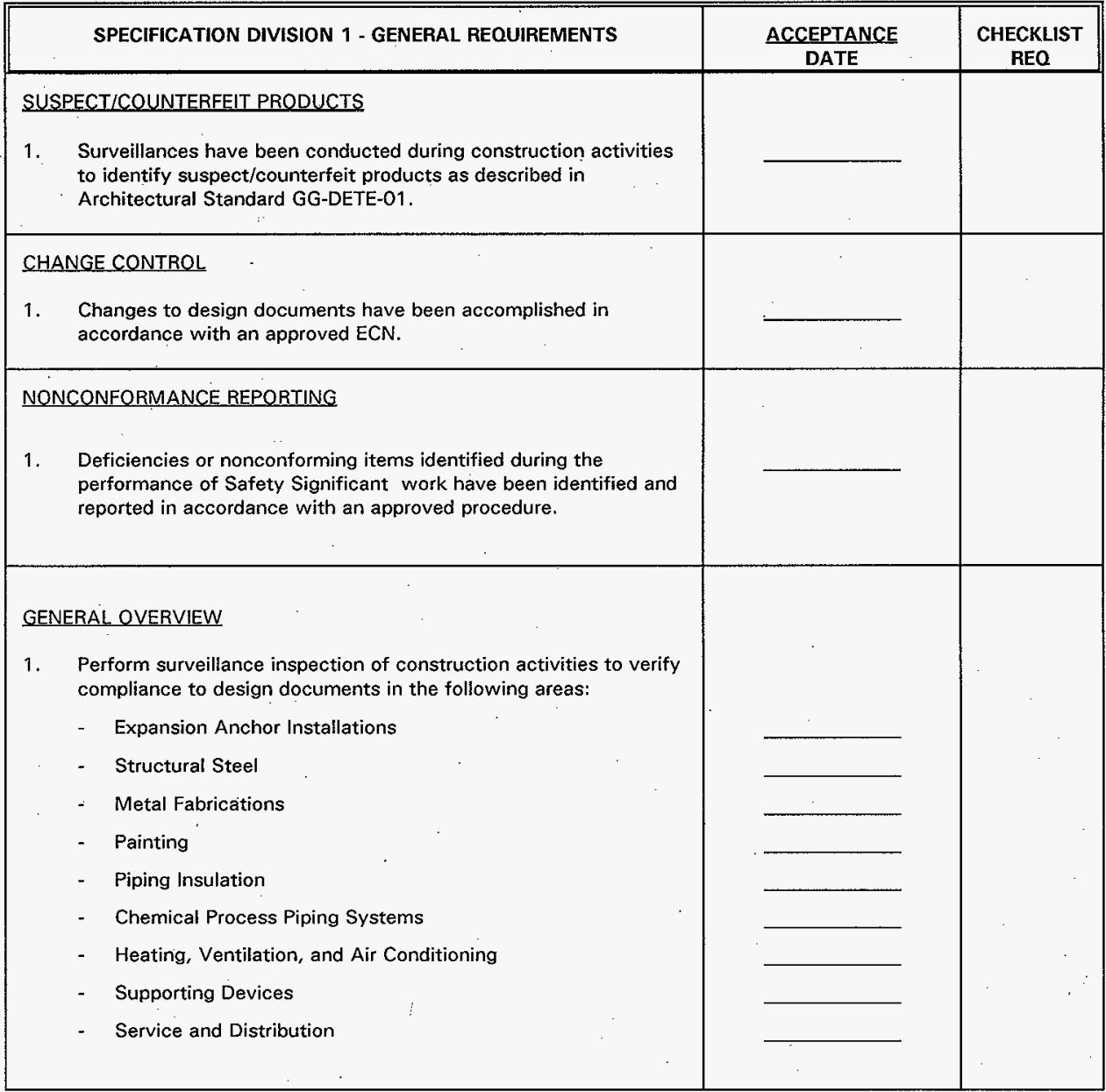


HNF-2065, Rev. 0

\begin{tabular}{|l|l|l|}
\hline SPECIFICATION DIVISION 1 - GENERAL REQUIREMENTS & $\frac{\text { ACCEPTANCE }}{\text { DATE }}$ & $\begin{array}{c}\text { CHECKLIST } \\
\text { REQ }\end{array}$ \\
\hline PUNCHLIST & & \\
1. Prepare the Official Project Punchlist. & & \\
\hline $\begin{array}{l}\text { OFFICIAL ACCEPTANCE } \\
\text { A Final Inspection shall be performed on all safety significant } \\
\text { installations, Equipment, and Components Constructed, } \\
\text { Fabricated, Modified, or Installed, to verify that work and } \\
\text { associated inspections have been completed and documented, } \\
\text { and that ail other requirements have been satisfied to allow } \\
\text { testing and operation to begin (HNF-PRO-263). } \\
\text { Sign the Acceptance of Completed Work form. } \\
\text { 2. }\end{array}$ & \\
\hline
\end{tabular}


HNF-2065, Rev. 0

SPECIFIC INSPECTIONS AND TESTING

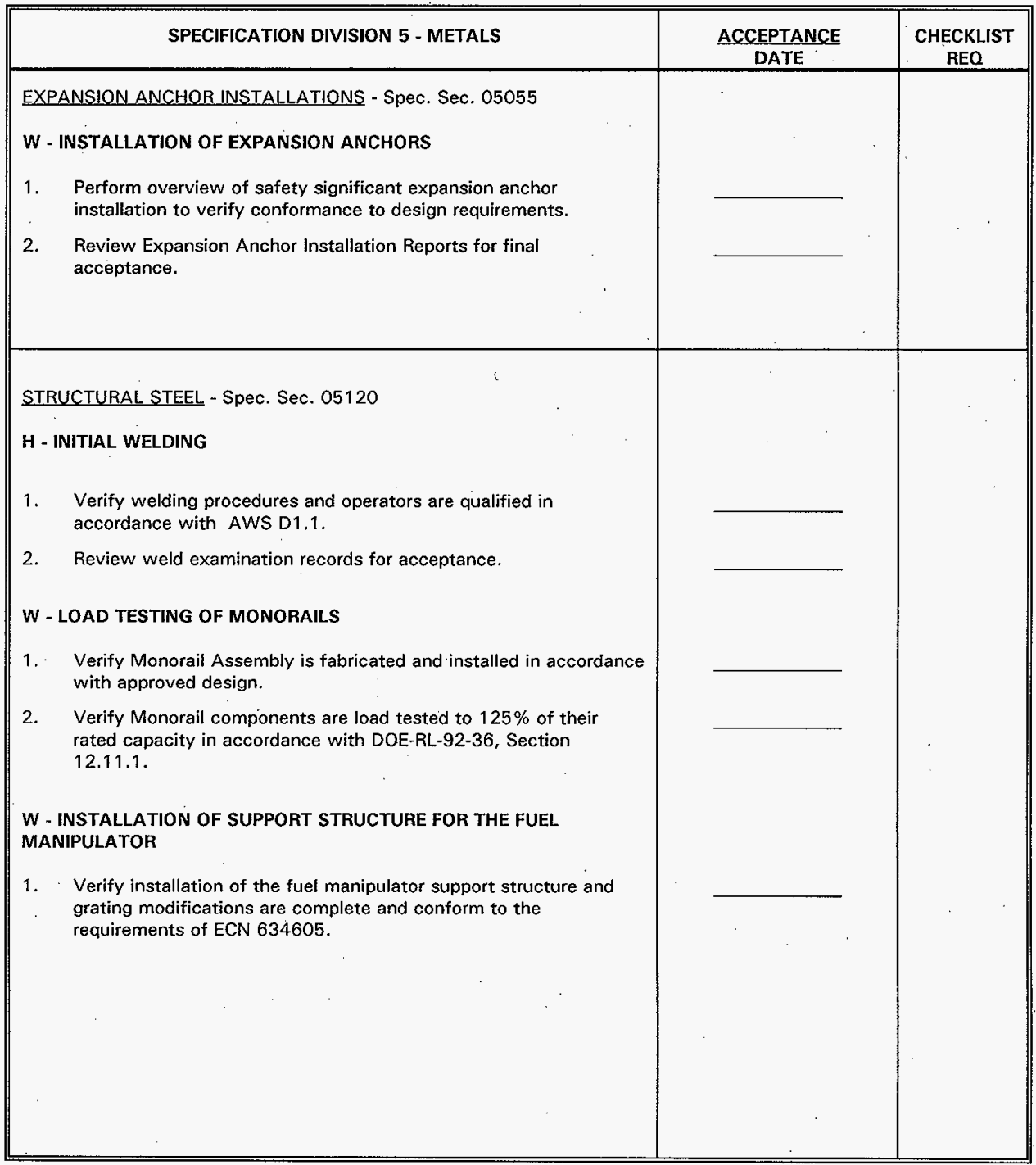


HNF-2065, Rev. 0

\begin{tabular}{|c|c|c|}
\hline SPECIFICATION DIVISION 15 - MECHANICAL & $\frac{\text { ACCEPTANCE }}{\text { DATE }}$ & $\begin{array}{c}\text { CHECKLIST } \\
\text { REQ } \\
\end{array}$ \\
\hline $\begin{array}{l}\text { CHEMICAL PROCESS PIPING SYSTEMS - Spec. Sec. } 15493 \\
\text { W - INITIAL WELDING } \\
\text { 1. Verify correct weld procedure utilized and welder's } \\
\text { qualified/certified. } \\
\text { 2. Review Process Control Package for acceptance of } \\
\text { documentation. } \\
\text { W- LEAK/PRESSURE TESTING } \\
\text { 1. Perform random inspection of the following attributes: } \\
\text { - Fiushing has been performed. } \\
\text { - Correct support types and span. } \\
\text { - All wall penetrations are sealed. } \\
\text { - Flange bolts are tightened. } \\
\text { Witness (Spot check) leak/pressure testing and verify } \\
\text { acceptability. Document on leak/pressure test certificate. }\end{array}$ & & \\
\hline $\begin{array}{l}\text { HEATING. VENTILATING, AND AIR CONDITIONING (HVAC) - SpEC } \\
\text { Sec. } 15500 \\
\text { W - LEAK/PRESSURE TESTING } \\
\text { 1. Perform random inspection of the following attributes: } \\
\text { - Correct location of HVAC unit(s). } \\
\text { - Bolted connections are tightened/torqued. } \\
\text { - Firestopping systems installed. } \\
\text { 2. Witness (Spot check) leak/pressure testing and verify } \\
\text { acceptability. Document on leak/pressure test certificate. } \\
\text { 3. Verify refrigerant application during vacuum testing. } \\
\text { 4. Review Test and Balance Data Report, and Control system } \\
\text { Functional Verification Report submitted by testing agency. }\end{array}$ & & . \\
\hline
\end{tabular}


HNF-2065, Rev. 0

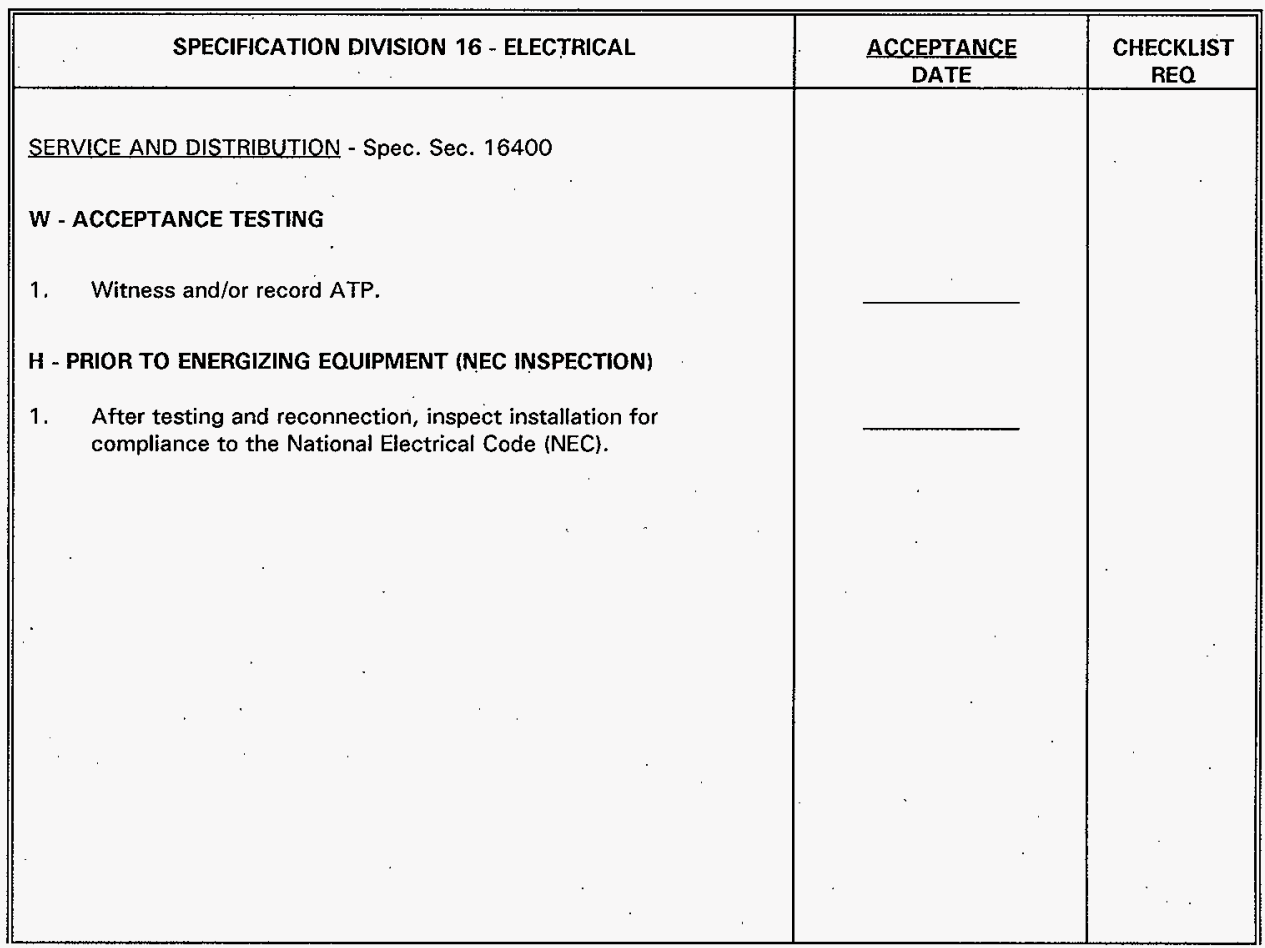


HNF-2065, Rev. 0

\section{FINALACCEPTANCE SHEET}

The following service requirements have been completed and accepted. Only services identified in the inspection plan will be listed in the Final Acceptance Sheet.

Initials Date

General Verifications and Surveillances

Specific Inspections and Testing

Metals

Finishes

Mechanical

Electrical 